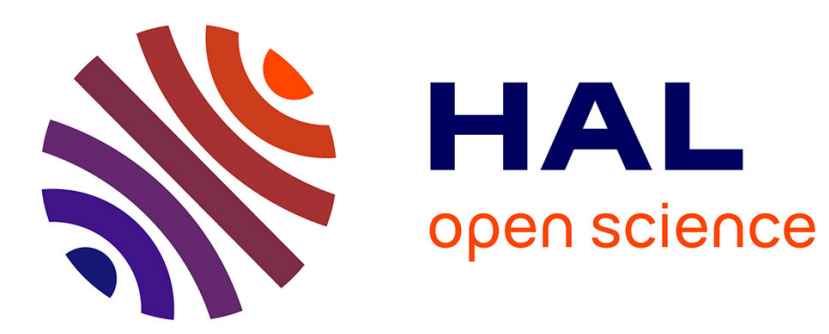

\title{
A case of type 1 achalasia associated with Parkinson's disease
}

\author{
M. Cheval, C. Villain, P. Gay, C. Toméo, Z. Barrou, M. Verny
}

\section{To cite this version:}

M. Cheval, C. Villain, P. Gay, C. Toméo, Z. Barrou, et al.. A case of type 1 achalasia associated with Parkinson's disease. Revue Neurologique, In press, 10.1016/j.neurol.2020.12.011 . hal-03269497

\section{HAL Id: hal-03269497 \\ https: / hal.sorbonne-universite.fr/hal-03269497}

Submitted on 30 Jun 2021

HAL is a multi-disciplinary open access archive for the deposit and dissemination of scientific research documents, whether they are published or not. The documents may come from teaching and research institutions in France or abroad, or from public or private research centers.
L'archive ouverte pluridisciplinaire HAL, est destinée au dépôt et à la diffusion de documents scientifiques de niveau recherche, publiés ou non, émanant des établissements d'enseignement et de recherche français ou étrangers, des laboratoires publics ou privés. 


\title{
A case of type 1 achalasia associated with Parkinson's disease
}

\author{
M.Cheval, C.Villain, P.Gay, C.Toméo, \\ Z.Barrou, M.Verny
}

Médecine Sorbonne Université, Centre de Gériatrie, Groupe Hospitalier Pitié-

Salpêtrière Charles Foix, Assistance Publique Hôpitaux de Paris, 47-83, boulevard de l'hôpital, 75013 Paris, France 
Swallowing disorders are common in patients with idiopathic Parkinson's disease (PD). It could result from global motor impairment, pharyngeal motor disorders or frequently associated esophageal motor disorders. We report the case of an 85-year old man patient who was admitted in our department for aphagia. Parkinson's disease (PD) had been diagnosed 5 years ago and was well controlled with levodopa and pramipexole. Dysphagia was present since the past two months, limiting ingestion of solid food and then fluids. A first gastroscopy had found peptic esophagitis but symptoms persisted despite double-dose proton pump inhibitors for one month. One week before hospital admission, symptoms rapidly worsened, leading to aphagia. He could no longer take his anti-Parkinsonian treatments and motor symptoms worsened. A nasogastric tube was placed. On the next day, the patient experienced hematemesis. Endoscopy was immediately performed and found a major stasis in a dilated esophagus with many blood clots and food residues, and an ulcerated esophagitis. Levodopa was not absorbed and a continuous subcutaneous apomorphine infusion was started. A chest CT-scan confirmed the major esophageal stasis and ruled out an extrinsic compression. After one week of strict fasting, a second endoscopy confirmed the esophageal dilatation with difficulty to pass throught the oesogastric junction. The patient underwent a barium esophagram which found a shrinked aspect of the lower sphincter of the esophagus (Figure 1). Ultimately, high-resolution esophageal manometry (Figure 2) showed a lack of peristalsis and a lack of relaxation of the lower sphincter allowing a diagnosis of type 1 esophageal achalasia. Shortly after diagnosis, a first session of endoscopic pneumatic dilation was realized and permitted the introduction a semi-liquid diet, with success. Two more sessions were scheduled and the patient was transferred to a rehabilitation unit for a renutrition program. 
Esophageal motility abnormalities are frequent in PD. In a cohort of 22 patients with PD, 16 (73\%) of patients had abnormal manometries [1]. These abnormalities are present from the early stage of disease: 25 to $30 \%$ of affected patients had PD diagnosed less than one year before and were not treated [3]. Su et al. [2] reported various manometric profiles, either isolated or combined: diffuse esophageal spasm in $48 \%$, ineffective esophageal peristalsis in $55 \%$, fragmented peristalsis in $48 \%$, oesogastric junction outflow obstruction in $39 \%$, or nutcracker esophagus. To the best of our knowledge, this is the first reported case of achalasia in a patient with PD. The pathological link between the two diseases has yet to be clarified. Some authors suggest that the accumulation of Lewy bodies in PD may begin in the gastrointestinal track and then expand to the central nervous system.

Esophageal motility abnormalities could be an early non-motor symptom of PD. These abnormalities are responsible for malnutrition, pneumonia, and death in patients with PD. They should be investigated because most of them can be treated with minimally invasive therapy (endoscopic botulinum neurotoxin injection [4], endoscopic dilation). 


\section{REFERENCES}

[1] Castell J. A., Johnston B. T., Colcher A., Li Q., Gideon R. M., Castell D. O. Manometric abnormalities of the oesophagus in patients with Parkinson's disease. Neurogastroenterol. Mot. (2001) 13, 361-364

[2] Su A., Gandhy R., Barlow C., Triadafilopoulos G. Clinical and manometric characteristics of patients with Parkinson's disease and esophageal symptoms Diseases of the Esophagus 2017, 30, 1-6 DOI: 10.1093/dote/dow038

[3] Hye Young S., Joong-Seok K., Kwang-Soo L. et al. The Prevalence and Patterns of Pharyngoesophageal Dysmotility in Patients with Early Stage Parkinson's Disease. Movement Disorders 2010, 25: 2361-2368

[4] Triadafilopoulos G., Gandhy R., Barlow C. Pilot cohort study of endoscopic botulinum neurotoxin injection in Parkinson's disease. Parkinsonism and Related Disorder 2017, 13538020. 


\section{FIGURES LEGENDS}

Figure 1: Barium esophagram : shrink aspect of the lower sphincter of the esophagus.

Figure 2 : High resolution manometry : type 1 esophageal achalasia
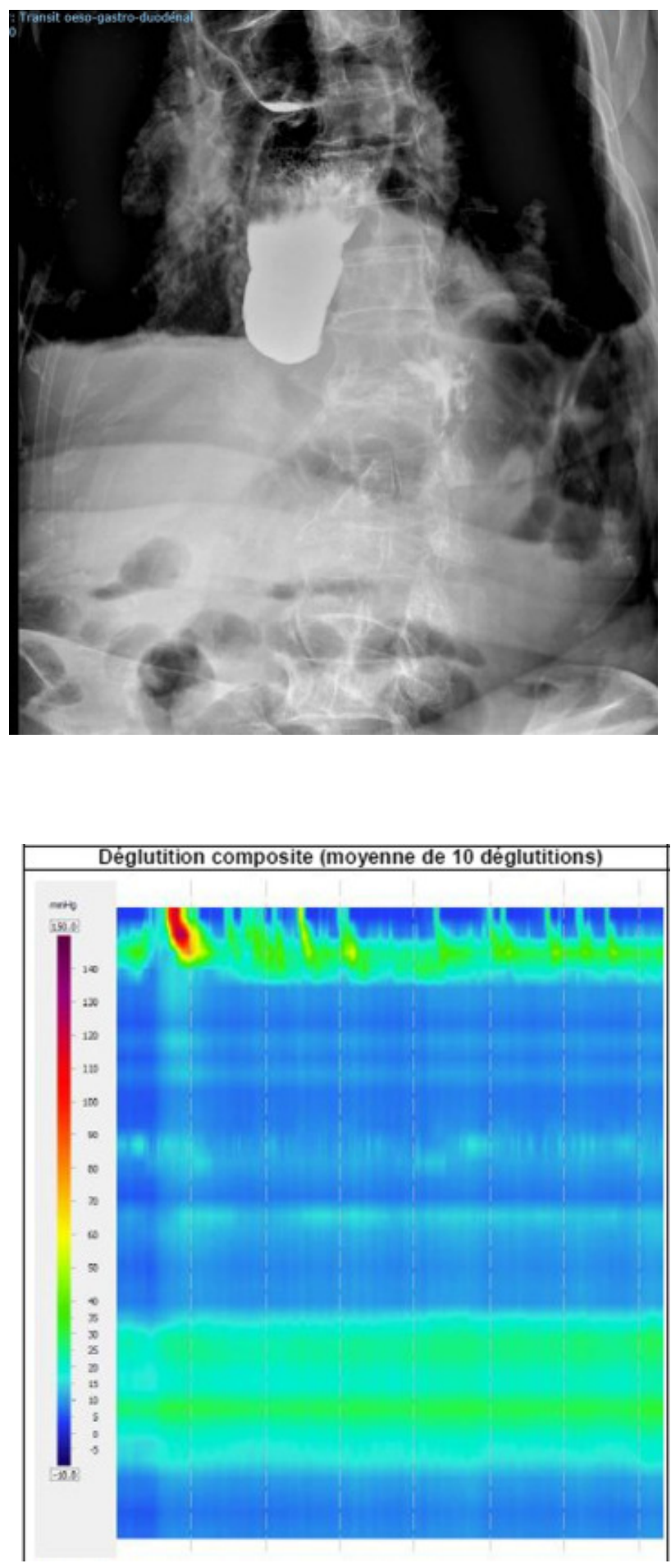